Jurnal Ilmiah Akuntansi Universitas Pamulang

Vol. 9, No. 1, Januari 2021

ISSN 2599-1922

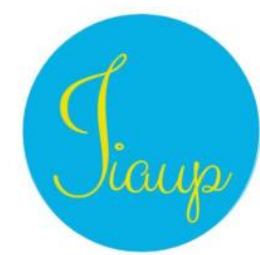

Received : 24 September 2020 Revised: 14 Desember 2020 Accepted: 31 Desember 2020 Published : 1 Januari 2021

\title{
MONEY ATTITUDE AND SOCIO-DEMOGRAPHIC FACTORS AS DETERMINANTS OF UNIVERSITY STUDENTS' SPENDING BEHAVIOR IN SHAH ALAM, MALAYSIA
}

\author{
JAMILAH KAMIS*, NORHASBI ABDUL SAMAD, LEE SIEW PHENG, SALINA \\ RASLI, SALBIAH HANUM MOHD HAJALI, SYLVIA EE FEE PEING \\ Universiti Selangor, Malaysia \\ *Email :jamilah@unisel.edu.my
}

\begin{abstract}
Nowadays, uncontrollable spending habit towards Malaysian young generations are becoming progressively. They have a tendency to have less value of money compared to the elder generations in spending their money. Since the cost of living in Malaysia has improved remarkably, the young generations enjoyed spending their money heavenly, therefore Malaysia faced changes in lifestyle and spending trend. This study proposes to investigate the relationship between money attitude and socio-demographic as determinants of college students' spending behaviours. As such, the correlation between money attitude factors (power-prestige, distrust, retention-time and anxiety) and spending behaviours among Malaysian college students is a topic worthy of further exploration. At the same time, this study also attempts to explore whether college students' spending behaviours are affected by their socio-demographic factors such as gender, age. The sample of this study consists of 176 students from three different universities in the Shah Alam area i.e University Selangor (UNISEL), University Management Science (MSU) and Universiti Teknologi Malaysia (UiTM). The regression analysis showed that there were only two factors of money attitude (power-prestige, and anxiety) that had a significant effect on spending behaviour among these universities' students. However, from the analysis, it can be revealed that none of the socio-demographic factors had a significance (more than 0.05) towards the spending behaviour of the students. Thus, age (positive result) is the most influenced factor of the students' spending behaviour. Consequently, several suggestions have been put forward and hoped that it will assist students in managing their fund effectively.
\end{abstract}

Keywords: Spending Behaviour; Money Attitude; Socio-Demographic

\section{INTRODUCTION}

Nowadays, uncontrollable spending habit towards Malaysian young generations are becoming progressively. They have a tendency to have less value of money compared to the elder generations in spending their money. Mohammed et al (2018) stated that since the cost of living in Malaysia has improved remarkably, 
Jurnal Ilmiah Akuntansi Universitas Pamulang - Vol. 9, No. 1, Januari 2021 Jamilah Kamis et al

the young generations enjoyed spending their money heavenly, therefore Malaysia faced changes in lifestyle and spending trend.

At the macro level, the number of bankruptcies in Malaysia is on the rise. The total number of bankruptcies was 299,186 as of December 2019 (refer to Table 1.1). Among those cases, more than a half (60.98\%) are Malaysians younger than 44 years old (Malaysian Department of Insolvency, 2019).

Table 1.1: Number of Malaysians Bankruptcy Cases Based on Ages (2017 to 2019)

\begin{tabular}{|c|c|c|c|c|c|}
\hline \multirow{2}{*}{ AGE } & \multicolumn{3}{|c|}{ YEAR } & \multirow{2}{*}{ TOTAL } & \multirow{2}{*}{$\%$} \\
\hline & 2017 & 2018 & 2019 & & \\
\hline Less 25 & 80 & 139 & 54 & 486 & 0.57 \\
\hline $25-34$ & 4,785 & 4,139 & 2,603 & 21,358 & 25.18 \\
\hline $35-44$ & 6,241 & 5,958 & 4,574 & 29,881 & 35.23 \\
\hline $45-54$ & 4,628 & 4,022 & 3,087 & 21,448 & 25.29 \\
\hline 50 Above & 2,354 & 2,106 & 1,707 & 11,002 & 12.97 \\
\hline No Information & 139 & 118 & 26 & 630 & 0.74 \\
\hline Total & 18,227 & 16,482 & 12,051 & 84,805 & 100.00 \\
\hline
\end{tabular}

Source: Malaysian Department of Insolvency, 2019

According to the Assistant Governor Nazrul Hisyam Mohd Noh of Bank Negara Malaysia (BNM), many Malaysian youths are suffering from the problem of high borrowings. As illustrated by him, $47 \%$ of our youth shave high credit card debts; $38 \%$ of them have been identified as having personal loans; and more than 3,400 of those between the ages of 20-30 years have sought assistance from the Debt Management and Counselling Agency (AKPK) (Bank Negara Malaysia, 2017). These figures point out that most likely the numbers of Malaysian youths facing financial difficulties are actually higher than those reported.

In this study, the researchers are going to investigate the correlation between money attitude and college students' spending behavior and identify the sociodemographic factors that are the most influential on college students' spending behavior. Students' spending trend nowadays are reflected to the changes of technology advancement and their lifestyles. Back then, students spent their money on stationeries, books but now, they more preferred in buying gadgets. Most of these studies demonstrate that the wrong money attitudes and irresponsible spending behaviors might become a prevalent issue among Malaysians, especially the youths. Therefore, the roots of these problems should be speedily identified so that effective national strategies can be designed and implemented to assist Malaysians in enhancing their financial literacy and planning wisely for their financial future. The researchers make a further investigation of the relationship of money attitude and socio-demographic factors that had positively affected university students' spending behavior.

\section{THEORETICAL FRAMEWORK}

\section{Spending Behaviour}

The concept of spending plays an important role in economic analysis since it facilitates the stability of economic growth (Perculeza et al., 2016). Longa et al 
Jurnal Ilmiah Akuntansi Universitas Pamulang - Vol. 9, No. 1, Januari 2021 Jamilah Kamis et al

(2013) specified the meaning of spending behaviour as the act of disbursing money in response to an action, environment, or person in the satisfaction of necessity. From the economist's perspective, John Maynard Keynes (1930) stated that an increase in spending would increase demand. Keynesians theory believed consumer demand is the primary trigger in an economy. However, Keynes argued that inadequate overall demand could lead to prolonged periods of high unemployment as cited in Jahan et al (2014).

Teng et al (2016) revealed money has existence everywhere especially in modern commercial society, money can shape the way people perceive themselves and influence how they behaviour. Asian countries especially Malaysia had recognised university student's expenditure as one of major contribution of the overall consumer spending (Sorooshian \& Seng Teck, 2014).

Being away from home, university students facing with spending behaviour shock. They have a unique spending habits due to limited incomes and high expenses; therefore, they manage money differently. Campus life has changed the students become more matured in making decisions in their lifestyles and may influence into improper spending behaviour (Rosmini \& Khalid, 2016).

The changes of students' spending behaviour reflected from the changes of technology advancement and their lifestyles. For example, in the past eras, books, stationeries, clothes, and other similar items for study were bought by the students. Whilst at the present time, student's necessities have been increased in addition where laptops and others gadgets especially smart phones are required for completing their coursework. Male students in particular are attracted to buy gadgets that are known to be costly, while the females more likely spent on shopping for clothes, bags and shoes are thought crucial, because they want to look nice going to classes (Sorooshian \& Seng Teck, 2014).

Spending behaviour and managing their own funding of these young people will affect their future financial status. Good spending habit is an important tool to one's financial success. Spending in a smart way takes your money to go further and lets you achieve your money goals (Bona, 2018). According to Jorgensen et al (2017), one of the possibly effective way to improve responsible spending behaviour's may be to identify and address attitudes related to overspending by university students.

\section{Money Attitude}

In economic perspectives, money is defined as a medium of exchange, a unit of account and a store of value. It is not only limited to that meaning, but it has also become the means and the end to happiness and wellbeing. Former researchers revealed money has existence everywhere especially in modern commercial society, money can shape the way people perceive themselves and influence how they behaviour (Teng et al, 2016). Therefore, money is a very important part of humans' life especially for universities students. According to Mulyani et al. (2018) that the teenagers interpret money as a tool of power, use money to either impress or dominate people, and regard money as a source of anxiety as well as a source of protection from anxiety. Therefore, the researchers in this study focused on attitude toward money of university students from four dimensions adopted from Money 
Jurnal Ilmiah Akuntansi Universitas Pamulang - Vol. 9, No. 1, Januari 2021 Jamilah Kamis et al

Attitude Scales (MAS) by Yamauchi \& Templer (1982) namely; power/prestige, retention, distrust and anxiety.

\section{Power/Prestige}

The 'prestige and power attitude' is defined by cognitive dimensions related to social connections, social prestige, and power linked to money (Yamauchi \& Templer, 1982). According to Henchoz et al (2019) found that there are three main types of attitudes towards money co-exist which are the prestige and power attitude, the money management attitude and the goal-oriented attitude. University students also look at money as a symbol of success and promote a sense of life achievement linked to the worship of money, materialism, vanity and an inflated ego (Durvasula \& Lysonski, 2010).

Manchanda (2017) from the study revealed that materialism and all its subdimensions i.e. material success, material centrality, and material happiness, were found to be positively correlated to power- prestige sub-dimension of money attitude among university students. It is supported by other researchers that money can buy things it can be used to acquire importance, domination, and control that bring a motivational power as well as to make people more secure (Furnham \& Murphy, 2018).

\section{Distrust/frugality}

Distrust is the MAS dimension developed by Yamauchi \& Templer (1982) which is insecurity in making a purchase and financial decisions. It includes constantly being suspicious of prices charged and hesitance when it comes to spending money due to the lack of confidence in their financial judgment. Consumers such as university students also who have a lack of trust in dealing with money are rated highly on the distrust dimension of MAS (Durvasula \& Lysonski, 2010). Manchanda (2017) study revealed the correlation between materialism and distrust among university students was found to be very low and insignificant. It shows that materialistic people do not believe in holding money for the future but spend on material goods.

\section{Retention Time}

Yamauchi \& Templer (1982) stated that the third dimension of MAS is retention time. This retention dimension promotes saving, prudent saving and money management (Nga \& Yeoh, 2015). People who rate high in this dimension are those who are concern about their financial future. In other words, they are more careful about monitoring their financial situations. It is stated from a research study, financial awareness among university students was found to have a positive influence on retention (Nga \& Yeoh, 2015).

Nevertheless, Manchanda (2017) stated that university students still tend to spend more compared to hold money for the future. His study showed that the correlation of materialism with retention-time was insignificant and very low.

\section{Anxiety}

The fourth dimension of money attitude is anxiety (Yamauchi \& Templer, 1982). He highlighted that money act as a medicine to release stress and depression. 
Jurnal Ilmiah Akuntansi Universitas Pamulang - Vol. 9, No. 1, Januari 2021 Jamilah Kamis et al

Those who score high under this dimension view money to reduce anxiety. Some researchers highlighted from the study, perceived stress on status and anxiety towards money had a strong positive impact on later-life affective money attitudes (Duh, 2016). Studies conducted among students university, those materialistic people tend to get anxious easily.

The anxiety sub- dimension of money attitude found to be significantly associated with materialism and all its sub-dimensions except material happiness. They spend on material goods, not for happiness, but they wanted to show off. Meanwhile, their perception of where spending money on goods for material happiness is not inconvenient to them (Manchanda, 2017).

\section{Socio-Demographic}

University students represent a large number of consumer segments in Malaysia. The sellers always try to reach the student market due to the reasons that they are normally a type of first-time purchase decisions without the influence of their parents. It is important to study on their shopping behaviour in order for the marketers to develop strategies to target them. This study therefore focuses on the effect of socio- demographics factors such as age, gender, source of income, level of education and area of studies on the university students' spending behaviour at the Institution of Higher Learning in Shah Alam.

According to Merriam-webster, there are a combination of social and demographic factors. An individual's socio-demographic characteristics include age, sex, education level, income level, marital status, occupation, employment status, ethnicity, religious affiliation, average size of the family, age at marriage, etc. Mohammand, et al (2016) identified that there were significant differences among demographic groups (gender, educational level and income per semester) in term of spending attitude. Rosmini \& Khalid (2016) argued that by observing the students' source of income, the type of expenditure incurred and amount spent will affect the way their spending behaviour.

The unnecessary spending behaviour is shown by not only female students, but male students as well. A study done by Sereetrakul et al (2013) revealed that, female and male students did not have different saving behaviour, although females had a more positive attitude towards saving and shopping than males. In addition, females were more concerned about being rich or having a lot of money than males, while males had a more positive attitude towards spending money than females. Traditionally, females have been the most energetic shoppers, controlling nearly $80 \%$ of household spending, conversely, Millennial male are changing the game where they preferred to spend more on entertainment, leisure, excitement, fun, gadgets and games (Venessa et al, 2017). However, Ibrahim et al. (2009) stated that male university students in Malaysia have more positive financial attitude than female students.

Social learning theory stated that parents and other influential individuals normally transmitted a learned spending behaviour from one generation to another generation (Maurice, 2016). Bona (2018) decided that university students' spending behaviour is greatly influenced by their family background. Birari \& Patil (2014) found out that students belonging to different education levels differ

* Corresponding author's e-mail: jamilah@unisel.edu.my

http://openjournal.unpam.ac.id/index.php/JIA 
Jurnal Ilmiah Akuntansi Universitas Pamulang - Vol. 9, No. 1, Januari 2021 Jamilah Kamis et al

significantly in spending in many categories.

Normally, financial support and loans are available to more students than ever before. Most fulltime students receive financial support, scholarship funding and a loan to offset the cost of university. Students need money for their tuition and living costs and usually the sources were form their education loan, allowances from their parents and form their part-time job. Currently, students' expenditure increased tremendously during their studies in higher learning. They spend most of their money not only on food, but a huge portion goes to gadgets such as cell phone service, entertainment and clothing (Sorooshian \& Seng Teck, 2014).

In order to support their needs and wants, most of the university students do part time job. Some asking from their parents' monetary support. Students who report coming from lower economic backgrounds may be more likely to be financially responsible and display positive behaviours. In addition, Sorooshian \& Seng Teck (2014) concluded that majority of the students do not put to practice correct skill in money management. Their study emphasized the need on financial literacy awareness among the students is a crucial issue.

\section{Conceptual Framework}

Figure 1 below shows the conceptual framework of this study to indicate the relationship between the independent variables towards dependent variable of the study

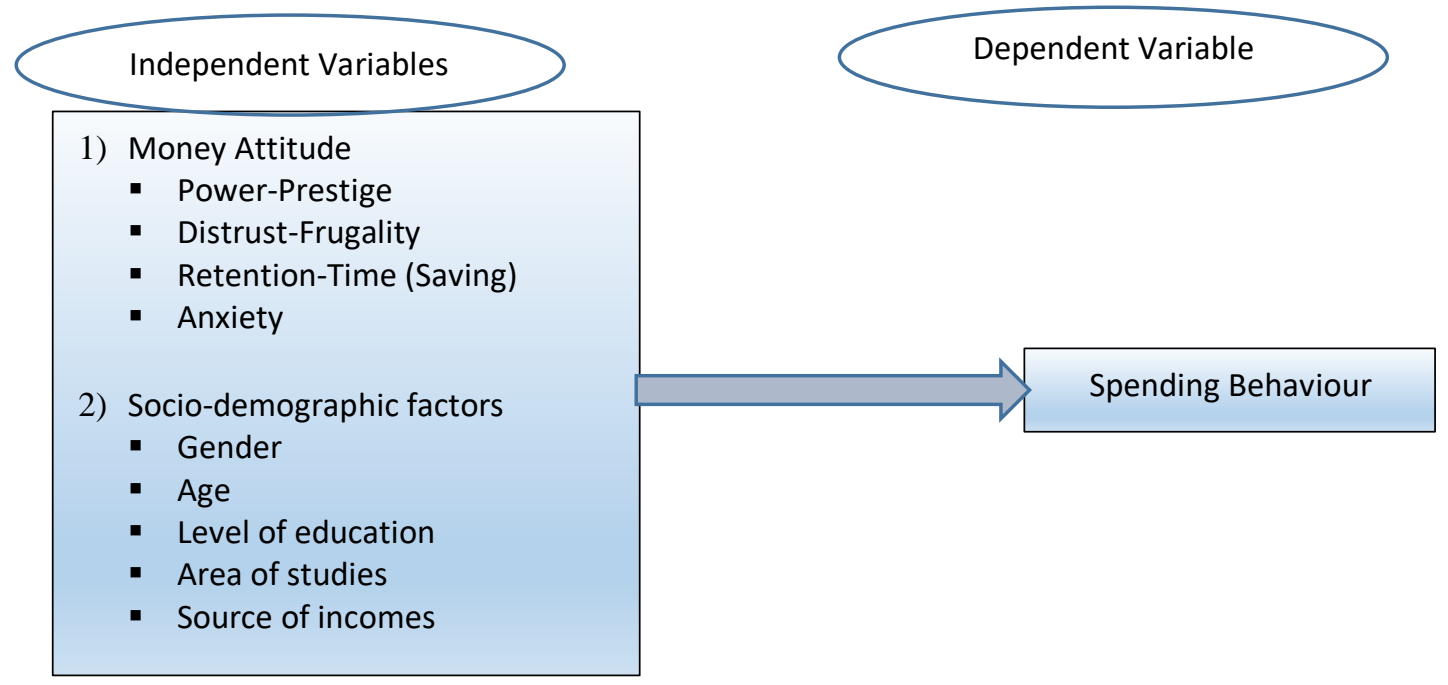

Figure 1: Conceptual Framework

The following hypotheses are:

H1: There is significant influences of money attitude and spending behavior

$\mathrm{H} 2$ : There is difference in financial behavior among college students of different demographic characteristics (Gender, Age, Level of education, Areas of studies and Income). 
Jurnal Ilmiah Akuntansi Universitas Pamulang - Vol. 9, No. 1, Januari 2021 Jamilah Kamis et al

\section{RESEARCH METHOD}

\section{Data Collection Techniques}

This study is quantitative in nature. Once the primary data is collected through questionnaire survey. This questionnaire used five Likert scale; 1-Strongly Disagree, 2- Disagree, 3-Neutral, 4-Agree and 5-Strongly Agree. This Likert used for section B under Money Attitude and section C for Spending Behaviour. Whereas, for section A, the researchers used nominal.

\section{Operational Definitions of Variables}

The study focused on attitude toward money from four dimensions adopted from Money Attitude Scales (MAS) by Yamauchi and Templer (1982) namely; power/prestige, retention, distrust and anxiety. It also covered on some sociodemographic factors such as age, gender, area and level of studies and source of income.

\section{Sample Collection Techniques}

The population is comprised of students from three universities around Shah Alam area. They are from Universiti Selangor (UNISEL), Management Science University (MSU) andUniversiti Teknology Mara (UiTM) Shah Alam campuses as Shah Alam is the centre of education in Selangor. They are either Malaysian and non-Malaysian students who are currently studying under the certificate, foundation/matriculation, diploma and bachelor's degree program. The target sample for this study is 200 respondents. However, only 176 respondents answered the questionnaire. All the samples are used for the purpose of this study.

\section{Data Analysis Techniques}

The SPSS version 21 being used for the data analysis. Subsequently, correlation analysis will be utilized to check if a significant relationship exists between respondents' money attitude factors and spending behaviour. Then, ANOVA (analysis of variance) will be applied to examine if significant differences among these students. Finally, regression analysis is used to identify the most influential socio-demographic factors that affecting respondents' spending behaviour.

\section{DATA ANALYSIS AND DISCUSSION}

\section{Data Analysis}

Table 4.1 shows the number of respondents from three universities in Shah Alam area; i.e Management Science University (MSU), Universiti Teknologi Mara (UiTM) and Universiti Selangor (UNISEL). Most of the respondents are from MSU (40.9\%) compared to other two universities; UiTM (22.2\%) and UNISEL (36.9\%). 
Jurnal Ilmiah Akuntansi Universitas Pamulang - Vol. 9, No. 1, Januari 2021 Jamilah Kamis et al

Table 4.1: Number of Respondents

\begin{tabular}{llcc}
\hline & $\mathrm{N}$ & $\%$ \\
\hline \multirow{4}{*}{ Valid } & MSU & 72 & 40.9 \\
& UiTM & 39 & 22.2 \\
& UNISEL & 65 & 36.9 \\
& Total & 176 & 100.0 \\
\hline
\end{tabular}

The strength of the relationship between money attitude factors and the spending behaviour of the universities students is shown in Table 4.2. It revealed that there are two out of four factors of money attitude are coefficient contribute to spending behaviour of the university's students. These factors are power and anxiety since it displayed 0.000 and 0.001 respectively. These variables are significant as the results shown less than 0.05. However, power is the most influential factor of money attitude towards spending behaviour which give the greater result of 0.236 or $23.6 \%$.

Table 4.2: Regression Coefficient between Money Attitude factors and Spending Behaviour

\begin{tabular}{llccccc}
\hline Model & & \multicolumn{2}{c}{ Unstandardized Coefficients } & $\begin{array}{c}\text { Standardized } \\
\text { Coefficients } \\
\text { Beta }\end{array}$ & $\mathrm{t}$ & Sig. \\
\hline \multirow{4}{*}{1} & B & Std. Error & .216 & & 7.862 & .000 \\
& (Constant) & 1.700 & .052 & .265 & 3.469 & .001 \\
& anxiety & .181 & .042 & -.116 & -1.727 & .086 \\
& retention & -.073 & .051 & .017 & .244 & .807 \\
& distrust & .012 & .047 & .376 & 4.973 & .000 \\
\hline
\end{tabular}

a. Dependent Variable: spending behaviour

Table 4.3 shows ANOVA analysis which illustrates that this model is significant. The p-value is less than 0.05 .

Table 4.3: ANOVA of Money Attitude factors and Spending Behaviour

\begin{tabular}{|l|c|c|c|c|c|}
\hline \multicolumn{1}{|c|}{ Model } & $\begin{array}{c}\text { Sum of } \\
\text { Squares }\end{array}$ & df & $\begin{array}{c}\text { Mean } \\
\text { Square }\end{array}$ & F & Sig. \\
\hline Regression & 15.933 & 4 & 3.983 & 17.655 & $.000^{\mathrm{b}}$ \\
\hline $1 \quad$ Residual & 38.807 & 172 & .226 & & \\
\hline Total & 54.740 & 176 & & & \\
\hline
\end{tabular}

a. Dependent Variable: spending behaviour

b. Predictors: (Constant), power, distrust, retention, anxiety

Table 4.4 indicated that only 0.291 or $29.1 \%$ of these money attitude factors that influence the spending behaviour of these three universities students.

Table 4.4: Model Summary

\begin{tabular}{lcccc}
\hline Model & $\mathrm{R}$ & $\begin{array}{c}\mathrm{R} \\
\text { Square }\end{array}$ & $\begin{array}{c}\text { Adjusted } \\
\text { R Square }\end{array}$ & $\begin{array}{c}\text { Std. Error of the } \\
\text { Estimate }\end{array}$ \\
\hline 1 & $.540^{\mathrm{a}}$ & .291 & .275 & .47500 \\
\hline
\end{tabular}

* Corresponding author's e-mail: jamilah@unisel.edu.my

http://openjournal.unpam.ac.id/index.php/JIA 
Jurnal Ilmiah Akuntansi Universitas Pamulang - Vol. 9, No. 1, Januari 2021 Jamilah Kamis et al

a. Predictors: (Constant), power, distrust, retention, anxiety

Table 4.5 shows the socio-demographic distribution of respondents. Majority $(57.4 \%)$ of the respondents are female that age ranged of less than 25 years old $(60.8 \%)$. Most of these respondents are from bachelor degree level of education which carried $80.7 \%$, whom from Accounting and Business field (71.6\%). It can be concluded that $47.7 \%$ of these students being sponsored by their parents whereas another $40.3 \%$ received loan or scholarship from government as their main sources of income.

Table 4.5: Socio-demographic Distribution of Respondents

\begin{tabular}{|c|c|c|c|c|c|}
\hline Demographic & Categories & $\mathrm{n}$ & $\%$ & Valid \% & Cumulative $\%$ \\
\hline \multirow[t]{2}{*}{ Gender } & Male & 75 & 42.6 & 42.6 & 42.6 \\
\hline & Female & 101 & 57.4 & 57.4 & 100.0 \\
\hline \multirow[t]{2}{*}{ Age } & $>25$ & 107 & 60.8 & 60.8 & 60.8 \\
\hline & $26-30$ & 69 & 39.2 & 39.2 & 100.0 \\
\hline Level of & Certificate & 3 & 1.7 & 1.7 & 1.7 \\
\hline \multirow[t]{3}{*}{ Education } & Foundation/Matriculation & 1 & .6 & .6 & 2.3 \\
\hline & Diploma & 30 & 17.0 & 17.0 & 19.3 \\
\hline & Bachelor Degree & 142 & 80.7 & 80.7 & 100.0 \\
\hline \multirow{5}{*}{$\begin{array}{l}\text { Areas of } \\
\text { Study }\end{array}$} & Accounting \& Business & 126 & 71.6 & 71.6 & 71.6 \\
\hline & $\begin{array}{l}\text { Education \& Social } \\
\text { Science }\end{array}$ & 9 & 5.1 & 5.1 & 76.7 \\
\hline & Engineering \& Information & 24 & 13.6 & 13.6 & 90.3 \\
\hline & Natural Sciences & 3 & 1.7 & 1.7 & 92.0 \\
\hline & $\begin{array}{l}\text { Communication, Art \& } \\
\text { Design }\end{array}$ & 14 & 8.0 & 8.0 & 100.0 \\
\hline \multirow{7}{*}{$\begin{array}{l}\text { Sources of } \\
\text { Incomes }\end{array}$} & Pocket money from parents & 84 & 47.7 & 47.7 & 47.7 \\
\hline & $\begin{array}{l}\text { Scholarship from } \\
\text { universities }\end{array}$ & 4 & 2.3 & 2.3 & 50.0 \\
\hline & $\begin{array}{l}\text { Scholarship/loan from } \\
\text { government }\end{array}$ & 71 & 40.3 & 40.3 & 90.3 \\
\hline & $\begin{array}{l}\text { Scholarship/loan from } \\
\text { private }\end{array}$ & 4 & 2.3 & 2.3 & 92.6 \\
\hline & Full time job & 5 & 2.8 & 2.8 & 95.5 \\
\hline & Part time job & 5 & 2.8 & 2.8 & 98.3 \\
\hline & Others & 3 & 1.7 & 1.7 & 100.0 \\
\hline
\end{tabular}

Table 4.6 reveals that there are none of the socio-demographic factors had a significance which more than 0.05 towards spending behaviour of these universities' students. However, age is the most influential factor of sociodemographic towards spending behaviour which give the greater result of 0.082 .

Table 4.6: Regression Correlation between Socio-Demographic and Spending Behaviour

\begin{tabular}{ccccc}
\hline Model & Unstandardized & Standardized & t & Sig. \\
& Coefficients & Coefficients & & \\
& B & Std. Error & Beta & \\
\hline
\end{tabular}

* Corresponding author's e-mail: jamilah@unisel.edu.my

http://openjournal.unpam.ac.id/index.php/JIA 
Jurnal Ilmiah Akuntansi Universitas Pamulang - Vol. 9, No. 1, Januari 2021 Jamilah Kamis et al

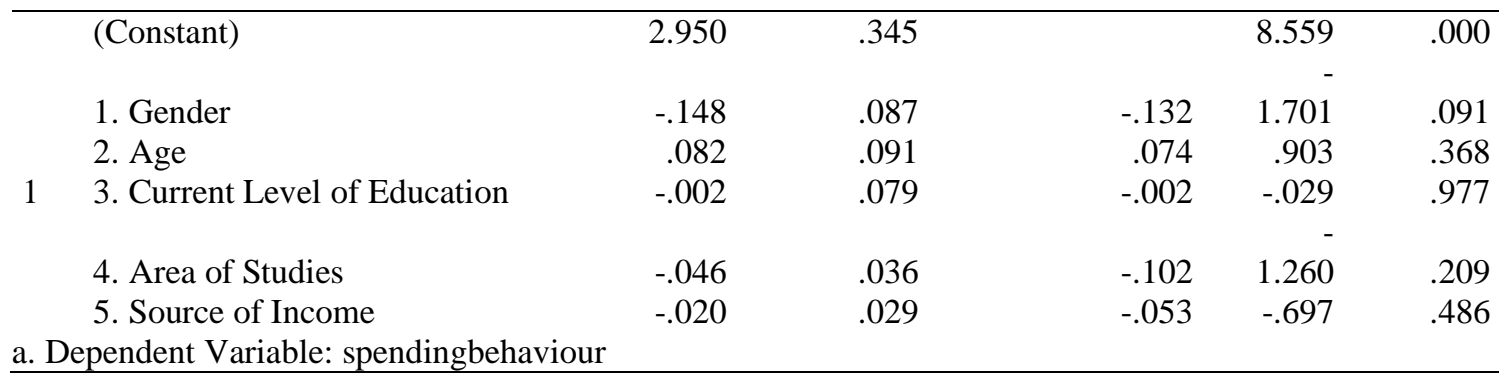

Table 4.7 indicates that there is no difference in style of spending behaviour of these students. All shows significant which is more than 0.05 . Their spending behaviour trend are most likely the same. Yet, UNISEL students showed a greater significance level i.e 0.725. It means that UNISEL students spent more compared to students from others universities.

Table 4.7: Comparison between Students' Spending Behaviour from Three Universities

\begin{tabular}{|c|c|c|c|c|c|c|}
\hline \multirow[t]{3}{*}{$\begin{array}{l}\text { (I) I am currently } \\
\text { enroll at: }\end{array}$} & \multirow[t]{3}{*}{$\begin{array}{l}\text { (J) I am currently } \\
\text { enroll at: }\end{array}$} & \multirow{3}{*}{$\begin{array}{c}\text { Mean } \\
\text { Difference } \\
(\mathrm{I}-\mathrm{J})\end{array}$} & \multirow[t]{3}{*}{$\begin{array}{l}\text { Std. } \\
\text { Error }\end{array}$} & \multirow[t]{3}{*}{ Sig. } & \multicolumn{2}{|c|}{$\begin{array}{l}\text { 95\% Confidence } \\
\text { Interval }\end{array}$} \\
\hline & & & & & Lower & Upper \\
\hline & & & & & Bound & Bound \\
\hline \multirow{3}{*}{ MSU } & Uitm & .18600 & .11062 & .215 & -.0755 & .4475 \\
\hline & UNISEL & .07260 & .09481 & .725 & -.1515 & .2967 \\
\hline & MSU & -.18600 & .11062 & .215 & -.4475 & .0755 \\
\hline \multirow[t]{2}{*}{ Uitm } & UNISEL & -.11340 & .11237 & .572 & -.3790 & .1522 \\
\hline & MSU & -.07260 & .09481 & .725 & -.2967 & .1515 \\
\hline UNISEL & Uitm & .11340 & .11237 & .572 & -.1522 & .3790 \\
\hline
\end{tabular}

Dependent Variable: spending behaviour

\section{Discussion}

From the outcomes above, the study can reveal some of the key underlying trends. First, power and anxiety become the most contributed spending behavior of the university's students around Shah Alam area. According to Falahati (2011), some students tend to use their money to influence others in order to have more power and some are more anxious about spending their money. This situation may due to transformations in the socialization process, past experiences, financial skills and knowledge about their money. However, Mulyani et al. (2018) stated that from their findings it showed most of the students preferred to spend their money on the cheaper price of the products. They are looking forward any offer or discounts given by the sellers. The students are more aware on their financially unsecured.

Secondly, spending behavior of the university's students reflect to the changes in aging factor. Adolescence have inadequate knowledge on their money management compared to adult. Therefore, they tend to lead financially mistakes on their spending behaviour (Mohammad, et al., 2016).

This study also showed that the spending behaviour of the students are similar in trend for all these three universities. However, UNISEL students are more 
Jurnal Ilmiah Akuntansi Universitas Pamulang - Vol. 9, No. 1, Januari 2021 Jamilah Kamis et al

spendthrift compared to other students from MSU and UiTM in spending their money. Although both UNISEL and MSU are private universities in Shah Alam area, it might be because of the study fees in UNISEL is much cheaper compared to MSU. Therefore, the students have more money to spend towards other expenses.

\section{CONCLUSION}

The recent study revealed that among the four money attitude factors, only power and anxiety factors are positively correlated to universities students' spending behaviour. It is also found that those money attitude factors explain $29.1 \%$ of the variance in students' spending behaviour.

Meanwhile, it is also concluded that age is the most influential sociodemographic factor which predicts universities students' spending behaviour.

Consequently, it is suggested to establish a technique in which students to manage their fund effectively, and this may influence students to appropriately accomplish their spending behaviour. As Nga \& Yeoh (2015) reported that money attitude awareness exercises positive influences on the spending behaviour of universities students.

By putting attitudes in its proper place, the spending behaviour among universities students in Malaysia is likely to change significantly when the desire to diversify beyond borrowing scheme is put into practice. Therefore, it is important for governments to devise borrowing policies and schemes that could guide universities students to proper manage their financial management.

This research focuses only universities' students in Shah Alam area as Shah Alam is the centre of education in Selangor. This study also can be extended in future towards other universities' students in Malaysia (public and private universities) in order to give more differences in their money attitudes and spending behaviour.

\section{REFERENCES}

Bona, J. T. C. (2018). Factors Affecting the Spending Behavior of College Students. Journal of Fundamental and Applied Sciences, 10(35), 142-152.

https://doi.org/http://dx.doi.org/10.4314/j fas.v10i3s.12

Campos Monteiro, D. L., Peñaloza, V., Pinto,F. R., Denegri CoriaM. del C., \& Orellana Calderón, L. M. (2015). Attitudes towards money and motivational orientation to work in Brazilian young workers. Contaduria $y$ Administracion, 60(1), 11-30. https://doi.org/10.1016/S01861042(15)72145-5

Duh, H. I. (2016). Childhood family experiences and young Generation Y money attitudes and materialism. 
Jurnal Ilmiah Akuntansi Universitas Pamulang - Vol. 9, No. 1, Januari 2021 Jamilah Kamis et al

Personality and Individual Differences, 95(68), 134-139.

https://doi.org/10.1016/j.paid.2016.02.02 7

Durvasula, S., \& Lysonski, S. (2010). Money, money, money - how do attitudes toward money impact vanity and materialism? - The case of young Chinese consumers. Journal of Consumer Marketing, 27(2), 169-179.

https://doi.org/10.1108/07363761011027 268

Falahati, L \& Laily Hj.Paim (2011). A comparative study in Money Attitude among University Students: A Gendered View. Journal of American Science, 2011;7(6)

Furnham, A., \& Murphy, T. A. (2019). Money types, money beliefs, and financial worries: An Australian study. AustralianJournal of Psychology, 71(2), 193199. https://doi.org/10.1111/ajpy.12219

Henchoz, C., Coste, T., \& Wernli, B. (2019). Culture, money attitudes and economic outcomes. Swiss Journal of Economics and Statistics, 155(1). https://doi.org/10.1186/s41937-019- 0028-4

Jorgensen, B. L., Foster, D., Jensen, J. F., \& Vieira, E. (2017). Financial Attitudes and Responsible Spending Behavior of Emerging Adults: Does Geographic Location Matter? Journal of Family and Economic Issues, 38(1), 70-83. https://doi.org/10.1007/s10834-016- 9512-5

Longa, I. V., \& Vergara, E. (2017). A qualitative study of spending behavior of ABM students in STI College Malolos, Bulacan.

Manchanda, R. (2017). Exploration of materialism and attitudes toward money in university students. JIMS8M: The Journal of Indian Management \& Strategy, 22(2), 45. https://doi.org/10.5958/0973- 9343.2017.00015.1

Maurice, D. (2016). Factors affecting the spending behaviour of Students. (March 2015). Retrieved from https://goo.gl/QHWrxF

Mohammand, Zuraida; Rashid, Kartini Mat; Baharuddin, Nurul Syuhada; Mansor, N. (2016). Antecedent affecting spending attitudes on Malaysian student. The Social Sciences, Vol. 11, pp. 7455-7460.

Mohammed, J., Alekam, E., Salniza, M., Salleh, B., \& Sanuri, S. (2018). The Effect of Family, Peer, Behavior, Saving and Spending Behavior on Financial Literacy among Young Generations. 7, 309-323.

Mulyani, S. H., Melmusi, Z., Okfrima, R., Lusiana, Farhannie, S., Noorma, \&Ismail, K. (2018). Money Attitudes Among Teenagers. Advanced Science Letters, 24(1), 334-337.

https://doi.org/10.1166/asl.2018.12001

Nga, K. H., \& Yeoh, K. K. (2015). Affective, social and cognitive antecedents of attitude towards money among undergraduate students: A Malaysian study. Pertanika Journal of Social Science and Humanities, 23(May), 161- 180. 
Jurnal Ilmiah Akuntansi Universitas Pamulang - Vol. 9, No. 1, Januari 2021 Jamilah Kamis et al

Perculeza, N. P. L., Andal, Y. P., Divino, M. A., Maderazo, C. J., Samonteza, Z., \& Manongsong, J. L. (2016). Spending behavior of the teaching personnel in an Asian University. 4(1), 99-108.

Rosmini, \& Khalid, K. (2016). Examining Undergraduates SpendingBehavior:the Case of Sultan Idris Education University. Examining Undergraduates SpendingBehavior:TheCaseofSultan Idris Education University, (DECEMBER2014).

Sereetrakul, W., Wongveeravuti, S., \& Likitapiwat, T. (2013). Gender differences in saving and spending behaviours of Thai students. Research in Education, 90(1), 68-81. https://doi.org/10.7227/RIE.90.1.5

Sorooshian, S., \& Seng Teck, T.(2014). Spending behaviour of a case of asian university students. Asian Social Science, 10(2), 64-69.

https://doi.org/10.5539/ass.v10n2p64

Teng, F., Chen, Z., Poon, K. T., Zhang, D., \& Jiang, Y. (2016). Money and relationships: When and why thinking about money leads people to approach others. Organizational Behavior and Human Decision Processes, 137, 58-70. http://doi.org/10.1016/j.obhdp.2016.08. 002

Venessa Funches, Yarber-Allen, A., \& Johnson, K. (2017). Generational and family structural differences in male attitudes and orientations towards shopping. Journal of Retailing and Consumer Services, 37(January), 101108. https://doi.org/10.1016/j.jretconser.2017. 02.016

Yamauchi, K. T., \& Templer, D. J. (1982). The Development of a Money Attitude Scale. Journal of Personality Assessment, 46(5), 522528.https://doi.org/10.1207/s15327752jpa460 5_14 